\title{
EFFICIENCY OF SOME BOTANICAL PRODUCTS IN CONTROLLING Varroa MITE INFESTING HONEYBEE COLONIES
}

\author{
(Received: 8.2. 2009)
}

\author{
By \\ S. I. Yousif-Khalil, A. M. Khater" and I. M. A. Ebadah ${ }^{* *}$ \\ Plant Protection Department, Faculty of Agriculture, Zagazig University, Egypt. \\ * Plant Protection Research Institute. Agricultural Research Center, Dokki, Giza, Egypt. \\ *National Research Center, Dokki, Giza, Egypt.
}

\begin{abstract}
The present investigation was carried out in the apiary of Beekeeping Research Department, Plant Protection Research Institute at Zagazig, Sharkia Governorate during 2007 season, to evaluate the efficiency of camphor salt, peppermint extract, thymol and formic acid (60\%) as control agents against Varroa mite infesting honeybee colonies. Data obtained could be summarized as follows:

1- Mite infestation was reduced by $69.01,48.92,75.95$ and $90.12 \%$ when the colonies were treated with camphor salt, peppermint extract, thymol crystals and formic acid, respectively.

2- The infested workers suffered $21.87 \%$ reduction in body weight while treating infested colonies with camphor salt, peppermint extract, thymol crystals and formic acid decreased the reduction in body weight to $11.84,13.87,5.91$ and $2.63 \%$, respectively.

3-Varroa infested colonies showed severe reduction $(47.96 \%)$ in the sealed brood area reared as compared to that of healthy ones. Treating infested colonies with the test control agents decreased the reduction taken place in sealed brood area, as it attained 20.85, 29.58, 15.69 and $13.11 \%$ for the treated colonies with test agents, respectively.

4- The mean annual honey yield (citrus and clover) of healthy, Varroa infested (non treated) colonies and those treated with camphor salt, peppermint extract, thymol crystals and formic acid recorded 8.06, $3.01,5.77,4.94,6.53$ and $7.15 \mathrm{~kg} /$ colony, respectively. The respective percentages of reduction in honey yield were 62.66, 28.41, 38.71, 18.98 and $11.29 \%$.
\end{abstract}

Key words: camphor salt, formic acid, honeybee colonies, peppermint extract, thymol, varroa mite.

\section{INTRODUCTION}

Varroa mite, Varroa destructor (jacobsoni) Oud. is considered one of the most dangerous beekeeping pests due to its capability of rapid and wide spreading and its power of destruction (Matheson, 1995). Therefore, many research works have been directed to control causative of this disease using different acaricides such as fluvalinate, Apitol, amitraz, etc. (Elzen et al., 1999 and Norberto, 1999).

However, the pollution of bee products, the developing of resistant strains of Varroa mite and other complications obligated the researchers and beekeepers to look for alternative more safer control measurements.

Therefore, the present work was designed to evaluate the efficiency of some control agents of botanical origin (camphor salt, peppermint extract, thymol crystals and formic acid) in controlling Varroa mite.

\section{MATERIALS AND METHODS}

The present investigation was carried out in the apiary of Beekeeping Research Department, Plant Protection Research Institute at Zagazig, Sharkia Governorate during 2007 season to evaluate the efficiency of some botanical materials in controlling Varroa mite infesting honeybee colonies.

\subsection{Materials used}

The following materials were used to control varroa mite infesting honey bee colonies. They were 6 secured from El-Gomhoreia Company for medical supplies and tools, zagazig Branch,Egypt.

\subsubsection{Camphor powder}

Powdered camphor (one tablet) was mixed with $20 \mathrm{~g}$ sugar powder to be dusted on the brood combs coverd with bees/colony. Four colony treatments were applied at 7 day intervals.

\subsubsection{Pepperment oil}

The peppermint (Mentha peperita) oil extract was obtained by boiling $500 \mathrm{~g}$ of leaves in 1.5 litres of water for 15 minutes. After filteration, the 
extract $(5 \mathrm{ml})$ was added to $500 \mathrm{ml}$ of sugar syrup $(1: 1)$ per colony. Four colony treatments were applied at 6-day intervals.

\subsubsection{Thymol}

Thymol crystals $(0.75 \mathrm{~g} /$ colony $)$ were kept in a perforated saccule to be hung between brood combs. Two colony treatments were applied at 10-day intervals.

\subsubsection{Formic acid}

Formic acid, at the concentration of $60 \%$ was applied on absorbent cardboard plates $(5 \times 20$ $\mathrm{cm})$ at the rate of $15 \mathrm{ml}$ per colony. The treated cardboard plates were placed over the top bars of the frames at the evening time. Four colony treatments were applied at 4-day intervals.

\subsection{Experimental honeybee colonies}

Three Varroa free-(healthy) and fifteen Varroa infested honeybee colonies (infestation range between $9-13 \%$ ) were used in the present study. The Varroa infested colonies were divided into 5 groups of 3 colonies each as follows:

Group 1: consisted of 3 healthy colonies used as +ve control

Group 2: consisted of 3 untreated Varroa infested colonies used as -ve control

Group 3, 4, 5 and 6 consisted of 3 infested colonies each and treated with camphor, peppermint, thymol and formic acid (60\%), respectively.

The tested colonies (except group 4) were fed with the same quantity of sugar syrup (1:1) during the period of study. Onset of the experimentation started on January 15 until the end of February, 2007.

The (pre-and post-treatment) Varroa infestation was assessed according to Shabanov et al. (1981). Thereafter, the rate of reduction in \% infestation was calculated according to Henderson and Tilton (1955) formula:*

*\% Reduction=

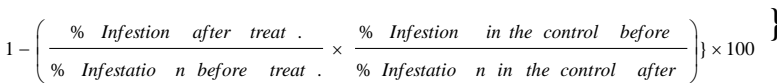

\subsection{The development of workers body weight}

The development of workers body weight was followed and recorded according to YousifKhalil (1992) method. This study was performed during March 2007.

\subsection{Evaluating brood rearing activity}

The areas of workers sealed brood cells present in the test colonies were measured separately, using Hoffman frame and divided into square inches at 12-day intervals from March to September, 2007.

\subsection{Estimating honey production}

The surplus honey combs were taken from their respective colonies after discarding the bees covering and marked with colour paint. Thereafter, honey yield was estimated for each colony separately (in $\mathrm{kg} /$ colony) by calculating the difference between the weight of honey combs before and after citrus and clover honey extraction.

Data obtained were statistically analysed according to Snedecor (1957) .

\section{RESULTS AND DISCUSSION}

3.1. Efficiency of the test control agents in reducing Varroa mite infestation

Data presented in Table (1) clear that the pretreatment mean rate of Varroa infestation recorded 12.66, 9.33, 11.66, 11.33 and $10.66 \%$. The respective post-treatment \% infestation attained 4.66, 5.66, 3.33, 1.33 and $12.66 \%$ after treating the colonies with camphor powder, peppermint extract, thymol, formic acid (60\%) and those untreated (control), respectively. The calculated rate of reduction in Varroa mite infestation recorded 69.01, 48.92, 75.95 and 90.12 $\%$ for camphor, peppermint, thymol and formic acid $(60 \%)$ treatments, respectively.

Analysis of variance revealed that formic acid was the most potent control agent followed by thymol whereas peppermint was the least effective agent. These results are in agreement with those of Clark (1994) and Mutinelli et al. ,(1997).

Table (1): Effect of the test control agents in reducing the rate of Varroa infestation in honeybee colonies during 2007 season.

\begin{tabular}{|l|c|c|c|}
\hline \multicolumn{1}{|c|}{ Treatments } & $\begin{array}{c}\text { Pre-treatment } \\
\text { infestation \% }\end{array}$ & Post-treatment infestation \% & Reduction \% \\
\hline Camphor salt & 12.66 & 4.66 & 69.01 \\
\hline Peppermint extract & 9.33 & 5.66 & 48.92 \\
\hline Thymol crystals & 11.66 & 3.33 & 75.95 \\
\hline Formic acid (60 \%) & 11.33 & 1.33 & \\
\hline $\begin{array}{l}\text { Control (untreated } \\
\text { colonies) }\end{array}$ & 10.66 & 12.66 & \\
\hline L.S.D. $\quad 0.05$ & & 0.68 & \\
\cline { 2 - 5 }$\quad \mathbf{0 . 0 1}$ & & 0.96 & \\
\hline
\end{tabular}




\subsection{Development of worker body weight}

Obtained results clear that the mean weight of newly emerged workers recorded 93.45, 91.35, $89.0,86.75,82.8$ and $70.05 \mathrm{mg} /$ worker arised in healthy colonies and those exposed to formic acid $60 \%$; thymol; camphor; peppermint extract and infested untreated colonies, respectively (Table 2). Analysis of variance indicated that Varroa infested (untreated) workers showed the least significant mean body weight. Formic acid and thymol caused noticeable positive effect while peppermint proved to be the least potent.

Thereafter, workers body weight increase was reported by Yousif-Khalil (1992) and AbdAlla (1999).

It is a well known fact that the adult Varroa females invade worker cells, containing grown larvae after larval feeding has been ceased and just before cell capping. Varroa mite (adult and immatures) usually feed (by sucking) on larval and pupal haemolymph containing digested food staffs and secretions needed for the development and metamorphosis of bees. Therefore, weight loss is expected, even if an efficient control measure is applied. De Jong and De Jong (1983) stated that the weight loss of newly emerged bees

Table (2): Development of workers body weight (mg) in different ages of healthy and Varroa mite infested honeybee colonies as affected with the tested control agents during 2007 season.

\begin{tabular}{|c|c|c|c|c|c|c|c|}
\hline \multirow{2}{*}{ Treatments } & \multicolumn{6}{|c|}{ Workers body weight (mg/individual) } & \multirow[b]{2}{*}{$\begin{array}{c}\text { Reduction } \\
\%\end{array}$} \\
\hline & $\begin{array}{c}\text { Newly } \\
\text { emerged }\end{array}$ & $\begin{array}{l}7 \text { day } \\
\text { old }\end{array}$ & $\begin{array}{l}14 \text { day } \\
\text { old }\end{array}$ & $\begin{array}{l}21 \text { day } \\
\text { old }\end{array}$ & Mean & $\begin{array}{l}\text { Weight* } \\
\text { index \% }\end{array}$ & \\
\hline Healthy colonies & 93.45 & 105.65 & 110.4 & 99.1 & 102.15 & 100 & - \\
\hline Formic acid $60 \%$ & 91.35 & 100.72 & 104.36 & 101.4 & 99.46 & 97.37 & 2.63 \\
\hline Thymol crystals & 89.0 & 98.05 & 102.4 & 95.0 & 96.11 & 94.09 & 5.91 \\
\hline Camphor salt & 86.75 & 97.0 & 99.0 & 85.65 & 92.10 & 90.16 & 11.84 \\
\hline Peppermint extract & 82.8 & 91.8 & 95.8 & 81.5 & 87.98 & 86.13 & 13.87 \\
\hline Infested colonies & 70.05 & 84.1 & 88.1 & 77.0 & 79.81 & 78.13 & 21.87 \\
\hline L.S.D. & 2.94 & 2.21 & 2.71 & 3.08 & 3.30 & & \\
\hline 0.01 & 3.82 & 3.59 & 3.61 & 4.50 & 4.15 & & \\
\hline
\end{tabular}

* Based on healthy colonies as $100 \%$

progressively by time, in all treatments until recording the heaviest body weight for 14-day old workers. The recorded body weight on that age reached 110.4, 104.36, 102.4, 99.0, 95.8 and 88.1 $\mathrm{mg} /$ worker for healthy, formic acid; thymol; camphor; peppermint extract treated colonies and infested untreated colonies, respectively. Workers of healthy colonies showed the heaviest significant mean body weight. On the other hand, infested workers possessed the lightest significant one. Formic acid $60 \%$ and thymol proved to be the most potent control agents, meanwhile peppermint was the least. Twenty one day old workers of all treatments suffered noticeable decrease in body weight.

Weight index data \{calculated basied upon healthy workers (the heaviest) are as $100 \%$ clear that body weights of the treated workers with formic acid, thymol, camphor and peppermint and untreated workers are 97.37, 94.09, 90.16, 86.13 and $78.31 \%$ as heavy as healthy workers.

In general, it could be concluded that the infested workers manifested the lightest significant body weights at all tested ages. However, the weight within the same group differed from one age to another, being the lightest for newly emerged and the heaviest for 14 day old worker in all treatments. The same trend may be due to the haemolymph sucked by the mite during pupal stage. Glinski and Jorosz (1984) and Ball (1993) found that the total protein content was lower in parasitized brood, probably due to either protein depletion in the host larvae, or as a result to biochemical changes following the release of toxic substances by the mite into the host's blood.

\subsection{Brood rearing activity}

Obtained results manifested relatively higher brood rearing activity starting from the beginning of March followed by a progressive increase by time until recording the first peak during the first week of April where the sealed brood area reached 246.6, 125.1, 189.6, 176.3, 206.8 and $211.2 \mathrm{inch}^{2} /$ colony in healthy, Varroa infested (untreated colonies) and those infested and treated with camphor, peppermint extract, thymol and formic acid, respectively. A gradual decrease was then taken place until May, 13, followed by irregular increase till recording a second peak detected during the $2^{\text {nd }}$ half of June. The third and the highest peak was detected on August, 17 (Table 3).

Analysis of data revealed that healthy colonies reared the highest significant sealed brood area on all peaks. On the other hand, 
S. I. Yousif-Khalil et al., ...........................................................................

Table (3): Brood rearing activity of healthy and Varroa infested honeybee colonies as affected by the test control agents during the active season of 2007.

\begin{tabular}{|c|c|c|c|c|c|c|c|c|c|c|c|c|c|c|c|c|c|c|c|c|}
\hline \multirow{2}{*}{ Date } & \multicolumn{17}{|c|}{ Sealed brood area (inch ${ }^{2} /$ colony) } & \multirow{2}{*}{ Total } & \multirow{2}{*}{ Mean } & \multirow{2}{*}{$\begin{array}{c}\text { Reduc } \\
\% \text { of } \\
\text { brood } \\
\text { area }\end{array}$} \\
\hline & $1 / 3$ & $13 . / 3$ & $25 / 3$ & $7 / 4$ & $19 / 4$ & $1 / 5$ & $13 / 5$ & $25 / 5$ & $7 / 6$ & $19 / 6$ & $1 / 7$ & $13 / 7$ & $25 / 7$ & $7 / 8$ & $17 / 8$ & $29 / 8$ & $11 / 9$ & & & \\
\hline Healthy colonies & 233.4 & 232.8 & 222.3 & 246.6 & 204.6 & 223.1 & 189.3 & 237.3 & 256.6 & 260.8 & 258.6 & 200.3 & 245.5 & 250.8 & 261.8 & 219.2 & 211.9 & 3954.9 & 232.6 & - \\
\hline Infested colonies & 128.8 & 134.8 & 117.1 & 125.1 & 140.8 & 122.6 & 122.3 & 123.5 & 113.6 & 119.8 & 120.8 & 109.3 & 105.3 & 117.8 & 125.6 & 120.1 & 110.3 & 2057.6 & 121.04 & 47.96 \\
\hline Camphor salt & 158 & 180.1 & 177.6 & 189.6 & 179.8 & 187.8 & 169.8 & 190.6 & 184.3 & 185.8 & 188.6 & 174 & 188.5 & 209.3 & 217 & 182.3 & 167.1 & 3130.1 & 184.1 & 20.85 \\
\hline $\begin{array}{l}\text { Peppermint } \\
\text { extract }\end{array}$ & 150.3 & 160.1 & 166.15 & 176.3 & 163 & 160.6 & 143 & 158.2 & 166.5 & 170.1 & 169 & 160.8 & 174.1 & 176.1 & 183.3 & 162.3 & 145.3 & 2785.1 & 163.8 & 29.58 \\
\hline Thymol crystals & 186.6 & 188.5 & 192 & 206.8 & 175.3 & 190.3 & 179.8 & 192.5 & 202.3 & 201.8 & 201 & 183.1 & 215.1 & 218.8 & 233.3 & 188.9 & 178.3 & 3334.4 & 196.1 & 15.69 \\
\hline Formic acid(60\%) & 198.4 & 201.2 & 191.2 & 211.2 & 186.4 & 197.5 & 184.6 & 198.1 & 207.5 & 200.3 & 204.1 & 190.6 & 220.3 & 224.1 & 237.2 & 191.4 & 183.5 & 3436.1 & 202.1 & 13.11 \\
\hline Total & 1055.5 & 1097.5 & 1074.8 & 1155.6 & 1049.9 & 1081.9 & 988.8 & 1100.2 & 1130.8 & 1138.6 & 1142.1 & 1018.1 & 1148.8 & 1196.9 & 1258.2 & 1064.2 & 996.4 & & & \\
\hline Mean & 144.8 & 182.9 & 179.1 & 192.6 & 174.9 & 180.3 & 164.8 & 183.3 & 188.4 & 189.7 & 190.3 & 169.6 & 191.9 & 199.4 & 209.7 & 177.3 & 166.0 & & & \\
\hline \multirow{2}{*}{$\begin{array}{rr}\text { L.S.D. } & 0.05 \\
& 0.01\end{array}$} & & & & & & & & & & & & & & & & & & & 37.44 & \\
\hline & & & & & & & & & & & & & & & & & & & 47.37 & \\
\hline
\end{tabular}


Efficiency of some botanicals products in controlling Varroa infested colonies reared the least significant area of sealed brood. Treating infested colonies with the test agents affected positively this activity. Formic acid proved to be the most potent agent followed by the thymol. The

that the Varroa mite infestation affected clearly honey production of the diseased honeybee colonies.

In this connection, Milne (1981) and Woyke (1984) reported that body weight, average daily brood production, workers longevity and

Table (4): Honey yield (kg/colony) of healthy and Varroa infested honeybee colonies as affected by the test control agents during 2007 season.

\begin{tabular}{|l|c|c|c|c|}
\hline \multirow{2}{*}{ Treatments } & \multicolumn{4}{|c|}{ Honey yield (kg/colony) } \\
\cline { 2 - 5 } & Citrus honey & Clover honey & Total honey yield & $\begin{array}{c}\text { Reduction \% of } \\
\text { production }\end{array}$ \\
\hline Healthy colonies & $2.75^{\mathrm{a}}$ & $5.31^{\mathrm{a}}$ & $8.06^{\mathrm{a}}$ & - \\
\hline Infested colonies & $0.95^{\mathrm{c}}$ & $2.06^{\mathrm{c}}$ & $3.01^{\mathrm{c}}$ & 62.66 \\
\hline Camphor salt & $1.91^{\mathrm{ac}}$ & $3.86^{\mathrm{b}}$ & $5.77^{\mathrm{b}}$ & 28.41 \\
\hline Peppermint extract & $1.56^{\mathrm{bc}}$ & $3.38^{\mathrm{b}}$ & $4.94^{\mathrm{bc}}$ & 38.71 \\
\hline Thymol crystals & $2.24^{\mathrm{ba}}$ & $4.29^{\mathrm{b}}$ & $6.53^{\mathrm{ab}}$ & 18.98 \\
\hline Formic acid $(60 \%)$ & 2.37 & $4.78^{\mathrm{ba}}$ & $7.15^{\mathrm{ab}}$ & 11.29 \\
\hline L.S.D 0.05 & 1.06 & 0.53 & 2.40 & \\
\hline \multicolumn{1}{|c|}{0.01} & 1.33 & 0.68 & 3.56 & \\
\hline
\end{tabular}

reduction in the realed sealed brood area due to mite infestation attained 47.96, 20.85, 29.58, 15.69 and $13.11 \%$ in infested untreated colonies and those treated with camphor, peppermint extract, thymol and formic acid, respectively.

The side effect of the chemicals used to control Varroa mite infesting honeybee colones is doubtless and was reported by many authors such as Henderson (1984), Milani and Borbattine (1988) and Herbert et al. (1988). Also Dimetry et al. (1995) reported that the amount of sealed and unsealed worker brood and the number of combs covered with bees were decreased in Folbex-VA treated colonies as egg laying activity of the queens was stopped for 3-4 days after each treatment.

\subsection{Honey production}

Data obtained cleared that the mean citrus honey yield recorded 2.75, 0.95, 1.91, 1.56 and $2.37 \mathrm{~kg} /$ colony, for healthy, Varroa infested untreated and treated colonies with camphor, peppermint, thymol and formic acid, respectively. The respective clover honey yield attained 5.31, 2.06, 3.86, 3.38, 4.29 and $4.72 \mathrm{~kg} /$ colony. The corresponding mean annual honey yield reached $8.06,3.01,5.77,4.94,6.53$ and $7.15 \mathrm{~kg} /$ colony for the forementioned treatments (Table 4).

The rate of reduction in honey yield due to Varroa infestation was $62.66 \%$ as compared to that of healthy colonies. Treating the infested colonies with camphor, peppermint, thymol and formic acid $(60 \%)$ improved honey yield of infested colonies, as the reduction percentages recorded 28.41, 38.71, 18.98 and $11.29 \%$, respectively. In this respect, Matter (1996) stated individual productivity of workers proved to play noticeable effects on honey production. The same conclusion was also reported by Mobus and Connor (1989), who stated that the diseased colonies have workers characterized with lower ability of flying to make collection tours, lower capacity of loading nectar and pollen and shorter life span.

In all cases control of Varroa mite using natural plant products are more recommended than other chemical acaricides to keep the social life of honey bee away from any harmful effects (Dimetry et al.,2005 and Abd El- Wahab and Ebadah , 2006).

\section{REFERENCES}

Abd-Alla M. A. (1999). Biological and Ecological Studies on Honeybee (Apis mellifera L.). M. Sc. Thesis, Fac. Agric., Zagazig Univ., Egypt.

Abd El- Wahab T.E. and Ebadah I.M.A.(2006). Evaluation of some volatile plant oils and mavrik against Varroa destructor in honeybee colonies. Journal of Applied Sciences Research, 2 (8): 514-521.

Ball B. V. (1993). The damaging effects of Varroa jacobsoni infestation. International Bee Research Association (IBRA), 9-16.

Clark A. (1994). Control of Varroa mites in British Colombia with either formic acid or Apistan. Am. Bee J. 134(2): 829.

De Jong D. and De Jong P. H. (1983). Longevity of Africanized honeybees (Hymenoptera: Apidae) infested by Varroa jacobsoni (Parasitiforms: Varroidae). J. Econ. Ent. 7: 766.768. 
Dimetry N. Z., Abd El-Wahab T. E. and Zakaria M.E.(2005). Effecive control of varroamite varroa destructor Anderson \& Trueman infesting honeybee colonies Apis mellifera $\mathrm{L}$. by some natural products. Bull.Fac. Agric., Cairo Univ., 56:295-308.

Dimetry N. Z., Salem M. S., Nour M. E. and Abd El-Wahab T. E. (1995). Efficiency of chemical control to Varroa mite (Varroa jacobsoni Oud.) and activities of honeybee colonies in Egypt. $1^{\text {st }}$ Conf. of Pest Control, Mansoura, Egypt, 1151-1161.

Elzen, P. J.; Boxter, J. R. and Winston W. (1999). Resistance mangments strategies for Varroa jacobsoni. In Proc. XXXVI ${ }^{\text {th }}$ Int. Cong. of Apimondia, Vancouver 12-17 Sept. 1999, Canada: 9.

Glinski, Z. and Jorosz J. (1984). Alterations in haemolymph proteins of drone honeybee larvae parasitized by Varroa jacobsoni. Apidologie 15(3): 329-337.

Henderson C.F. and Tilton E. W. (1955). Test with acaricides against the brown wheat mite, J. Econ. Ent., 48: 157-161.

Henderson G. (1984). Tests of chemical control agents for Varroa jacobsoni in honeybee packages. Africanized honeybees and bee mites, 380-386.

Herbert E. W., Bruce W. A. and Shimanuki H. (1988). Control of Varroa jacobsoni on honeybees in packages using Apistan. Am. Bee J. 128: 615-615.

Matheson A. (1995). World bee health update. Bee World, 76: 31-39.

Matter E. Z. N. (1996). Effect of Varroa Infestation on Honeybees, Apis mellifera L. M. Sc. Thesis, Fac. Agric., Zagazig Univ., Egypt.

Milani, N. and Borbattini R. (1988). Effectiveness of Apistan (fluvalinate) in the control of
Varroa jacobsoni Oudemans and its tolerance by Apis mellifera L. Apicoltura, 4: 39-58.

Milne, C. P. (1981). Laboratory measurement of honey production in the honeybee, longevity or length of life of caged workers, Journal of Apicultural Research, 19: 172-175.

Mobus, B. and Connor L. (1989). The varroa handb., Biology and Control. North Bee Books, Mythomroyd, Hebden Bridge, UK. PP. 52.

Mutinelli, F., Baggio A.; Capolongo F.; Riro R. and Biasion L. (1997). Oxalic acid in control Varroa mites. Ape Nostra Amica, 19(4): 4-6 (AA 693/98).

Norberto, M. (1999). The resistance against acaricides warring problem in the control of $V$. jacobsoni. In Proc. XXXVI ${ }^{\text {th }}$ Int. Cong. of Apimondia, Vancouver 12-17 Sept. 1999, Canada: 57.

Shabanov M. , Nedyakov S. and Toshkov A. (1981). Eine schnelle einfache Methode zur Varroatose. Diagnose pp. 108 from Diagnos und therapic varroatose. Buchates, Romania. Apimodia Publ. House (c.f. Bee World 62 (4))

Snedecor G. W. (1957). Statistical Methods Applied to Experiments in Agriculture and Biology. The Iowa State College Press, $5^{\text {th }}$ ed. Iowa, USA.

Woyke, J. (1984). Correlation and interaction between population length of worker life and honey production by honeybees in temperate region. J. Apic. Res. 23(3): 148-156.

Yousif-Khalil, S. I. (1992). Effect of Varroa infestation on the mortality rate, body weight and development of hypopharyngeal glands of honeybee workers. Zagazig Jour.Agric. Res. 19(2): 901-908.

$$
\begin{aligned}
& \text { كفاءة بعض المنتجات النباتية في مكافحة طفيل الفاروا الذي يصيب طوائف نحل العسل } \\
& \text { سعد إبرا هيم يوسف خليل- على محمد خاطر * - إبراهيم محمد عبد المنعم عبادة** }
\end{aligned}
$$

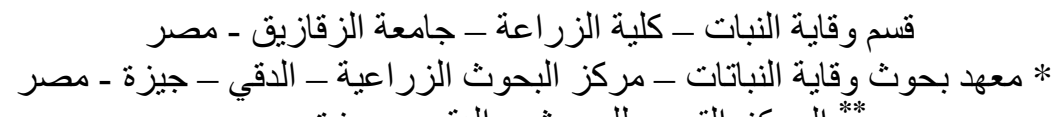

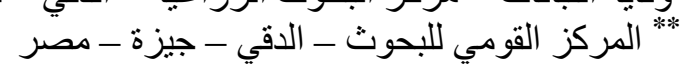

$$
\begin{aligned}
& \text { ملخص }
\end{aligned}
$$

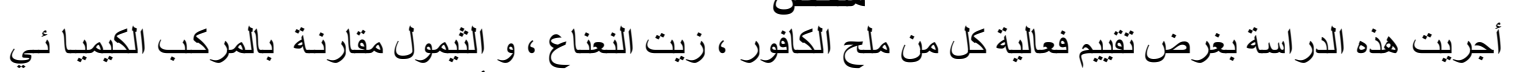

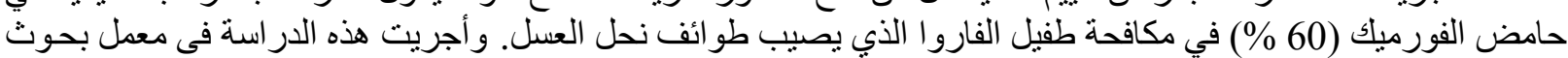

$$
\begin{aligned}
& \text { النحل ، معهد بحوث وقاية النباتات بالزقازيقـ الثرقية خلارول موسم } 2007 \text { ويمكن تلخيص النتائج كالاتى: }
\end{aligned}
$$




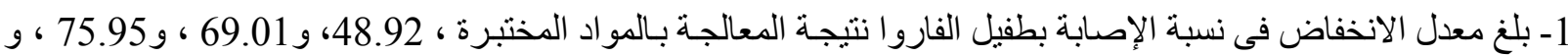

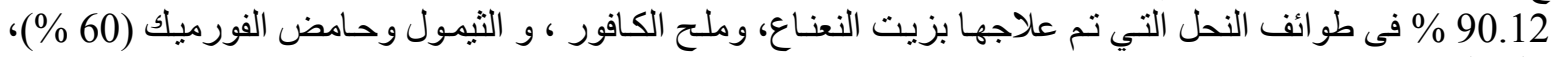
على الترتيب.

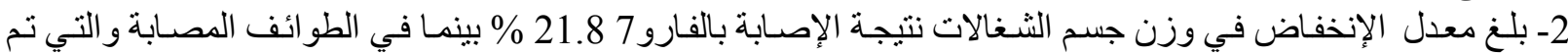

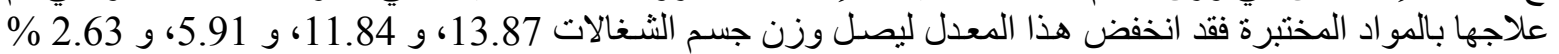

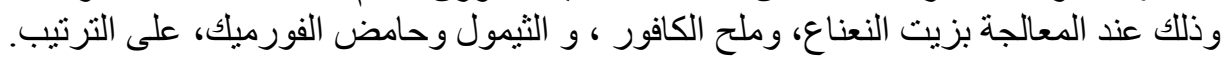

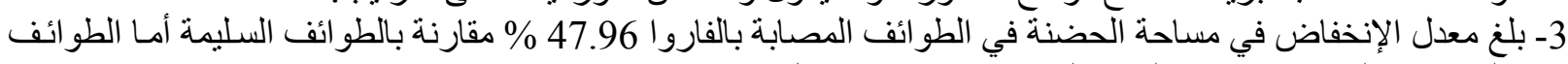

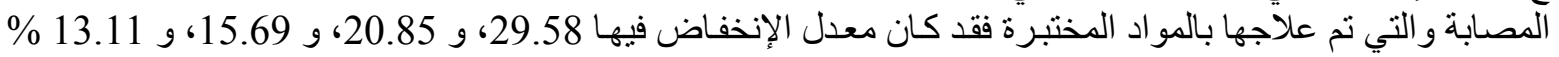

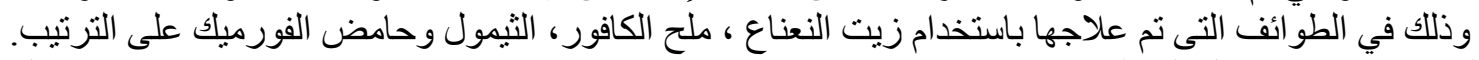

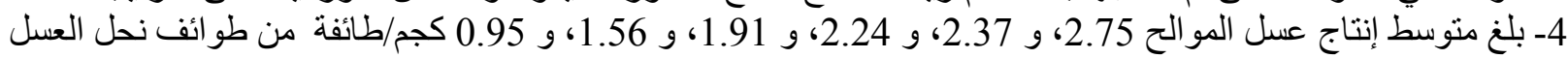

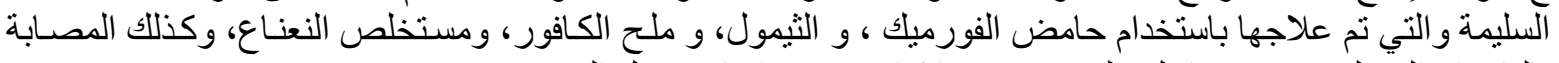

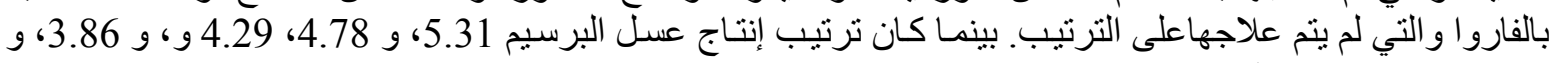

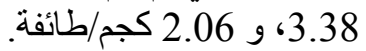

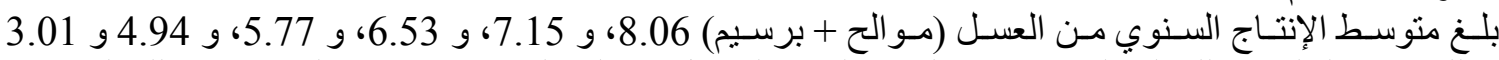

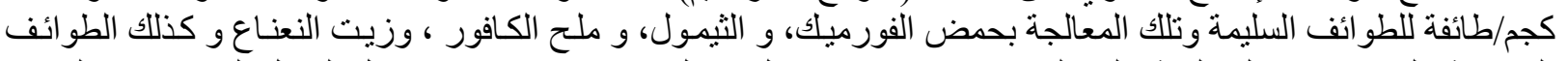

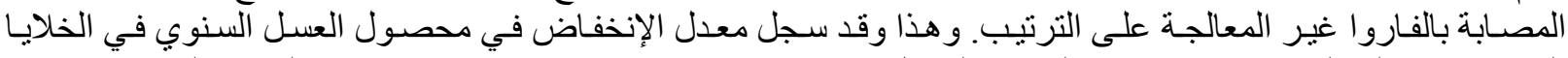

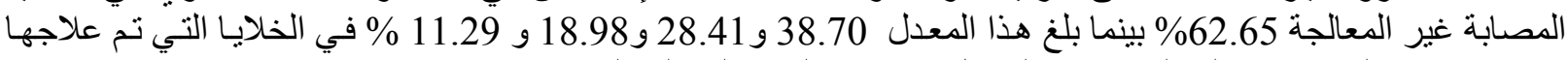

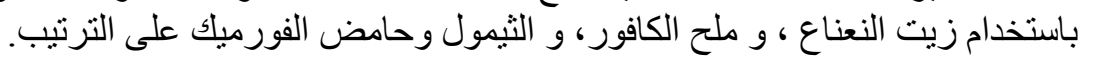

